\title{
The relation between yield indices of maize plant and soil physicochemical characteristics
}

\author{
Nalan Kars a, Imanverdi Ekberli b,*
}

a Republic of Turkey Ministry of Agriculture and Forestry, Black Sea Agricultural Research Institute, Samsun, Turkey

b Ondokuz Mayıs University, Faculty of Agriculture, Department of Soil Science and Plant Nutrition, Samsun, Turkey

\section{Article Info}

Received : 19.02 .2019

Accepted : 04.11.2019

\begin{abstract}
The aim of this study was to set regression models based on correlation between yield parameters of maize plant (height, thousand seed weight and yield) and physical and chemical characteristics of soils and to determine applicability of obtained models in estimation of plant yield grown in soils of Çarşamba Plain. Regression coefficient (R), root mean square error (RMSE), index of agreement $(d)$, model efficiency (ME) were evaluated to determine the validity of regression models between the yield components and physical and chemical characteristics of 40 soil samples taken from root zone of cultivated farms. Model associated with the relation between (i) plant height and bulk density (BD), field capacity (FC), clay and sand content wasn't statistical significant $(R=0.53, p>0.05)$; (ii) thousand seed weight and soil electrical conductivity (EC), organic matter (OM), lime $\left(\mathrm{CaCO}_{3}\right)$, nitrogen $(\mathrm{N})$, phosphorus $(\mathrm{P})$, potassium $(\mathrm{K}), \mathrm{Ca}+\mathrm{Mg}$ was characterized with a moderate $R(R=0.79, p<0.05)$, and (iii) seed yield and $\mathrm{OM}, \mathrm{N}, \mathrm{P}, \mathrm{K}$, copper $(\mathrm{Cu})$, cation exchange capacity (CEC), $\mathrm{CaCO}_{3}$ indices has the highest $\mathrm{R}(R=0.87 ; p<0.01)$. In general, statistical parameters were within the validity limits. The established regression models can be applied for the predicting of yield parameters of maize plant grown in the farmed areas of the region.
\end{abstract}

Keywords: Soil physicochemical properties, plant height, regression models, seed yield.

(C) 2020 Federation of Eurasian Soil Science Societies. All rights reserved

\section{Introduction}

In order to meet the nutritional needs of the growing world population with the existing agricultural lands, the need to obtain higher yields from the unit agricultural land has emerged, increasing and estimating the productivity is one of the current and research priority issues. It depends on the physical, chemical and biological properties of the soil along with management, environmental and genetic factors for high yield. For this reason, the researchers (Carena et al., 1987; Ekberli and Dengiz, 2016; Kars and Ekberli, 2019a) tried to establish the relationship between soil characteristics and yield parameters of various plants, since it was emphasized as a necessary step to access methods for protection, estimation and increase of productivity. In many studies, plant height, thousand seed weight and seed yield, are reported to vary significantly and depending on factors such as soil properties, plant genotype and sowing frequency, and environmental conditions (Whitman et al., 1985; Dotlacil and Toma, 1991; Peterson et al., 1992; Maiti and Wesche-Ebeling, 1998).

In the Çarşamba Plain, which has the most important agricultural potential in the Black Sea region of Turkey, the most recent cultivation area of the maize plant is $4038 \mathrm{ha}$, the production is 27021 tons and the yield is $706 \mathrm{~kg} \mathrm{da}^{-1}$ (Anonymous, 2019). Maize has a higher benefit from sunlight than other cultivated plants (cotton, wheat, rice). This leads to the formation of more dry matter and better utilization of the nutrients present in the maize plant soil, resulting in higher yields per unit area (Çolakoğlu, 1985). It has been

\footnotetext{
${ }^{*}$ Corresponding author.

Ondokuz Mayis University, Faculty of Agriculture, Department of Soil Science and Plant Nutrition, 55139 Samsun, Turkey

Tel.: +903623121919

E-mail address: iman@omu.edu.tr

e-ISSN: 2147-4249

DOI: $10.18393 /$ ejss.644038
} 
reported, that thousand seed weight of maize plant is positively correlated to its yield and thousand seed weight decreases when yield decreases (Angelov, 1994).

Regression models have wide applications in the fields of ecology, hydrology and agriculture as well as in soil and plant sciences, where parallel to the accumulation of sufficient level of soil and plant data, such models have been used appropriately. Making and using regression models in soil and plant ecosystem are expressed more easily and practical than theoretical model wth partial differential equations (Bayraklı et al., 1999; Overman and Scholtz, 2002; Gülser, 2004; Huang et al., 2014; Dorsey and Hardy, 2018; Thiéry et al., 2018; Kars and Ekberli, 2019b). Using both experimental (regression) and theoretical models may accept several assumptions and similar contribution of the used parameters (Bouma and van Lanen, 1987; Pachepsky and Rawls, 2004). With the help of regression models, quantitative relationships between yield parameters (biomass or height, thousand seed weight, seed yield) of various plants and easily determined physical and chemical properties of soil associated with soil quality and management can be explained (Vereecken et al., 2010; Gülser et al., 2016; Dengiz and Ekberli, 2017). The use of different statistical parameters to determine the validity of regression models is one of the important and necessary stages in model creation. Applicability of regression models mostly determined by the statistical parameters such as the root mean square error (RMSE), index of agreement $(d)$, maximum relative error (MRE), mean of absolute error (MAE), coefficient of determination (R) (Alexandrov and Hoogenboom, 2000; Budka et al., 2015).

This resarch was carried out to determine the correlation between some physical and chemical properties of cultivated soils with traditional tillage method and yield parameters of maize plant in Çarşamba Plain, Samsun, and to establish regression models among these properties, and to determine the applicability of the obtained models in the estimation of plant yield.

\section{Material and Methods}

The research was carried out in the territory of 20 villages representing the Çarşamba Plain of Samsun province in 2013-2014. In each year 20 soil samples were taken from 0-20 cm depth of the cultivated farm fields. The method shown in Anonymous (2018) was used to collect plant samples from the same areas. The locations where soil and plant samples taken were shown in Figure 1.

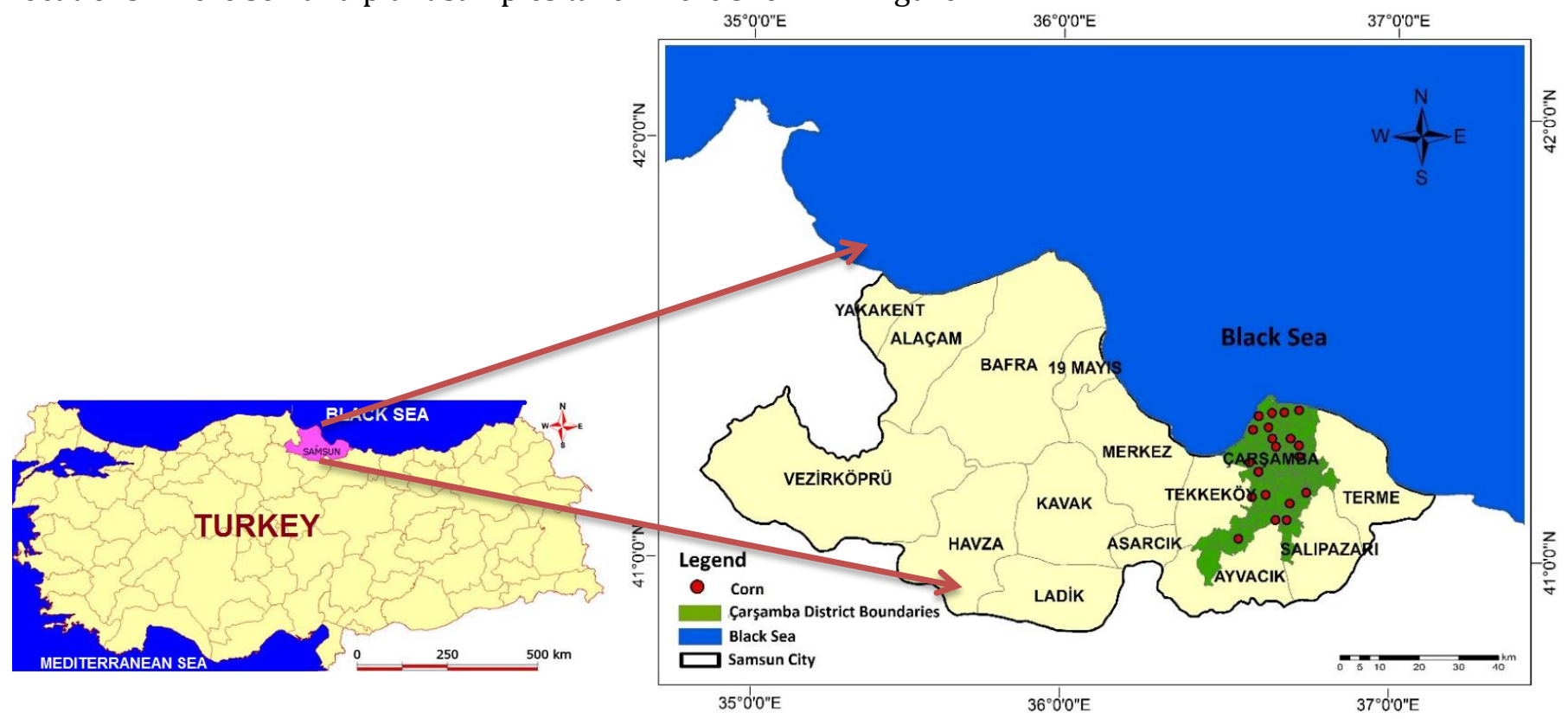

Figure 1. Locations where soil and plant samples were taken

Soil samples were air dried and sieved from a screen with $2 \mathrm{~mm}$ opening size to prepare for analysis. Sand, silt, clay contents of the soil samples were determined by hydrometer method (Bouyoucos, 1962). Bulk density (BD) values were determined by soil core method (Demiralay, 1993). Soil pH values were measured in soil suspension $(1: 1 \mathrm{w}: \mathrm{v})$ by glass electrode $\mathrm{pH}$ meter, and EC values were determined in the same soil suspension (1:1 w:v) by EC meter (Rowell, 1994). Soil organic matter (OM) contents were determined by modified Walkley-Black method, (Walkley and Black, 1934). Determination of soil chemical properties was conducted by the following approach: lime $\left(\mathrm{CaCO}_{3}\right)$ contents by Scheibler calcimeter according to Nelson (1982), and total nitrogen (N) contents by Kjeldahl method (Kacar, 1994), exchangeable cations (Ca, Mg, K, $\mathrm{Na}$ ) by ammonium acetate extraction (Kacar, 1994), available phosphorus by Olsen's method (Olsen et al., 
1954), DTPA extractable heavy metals (Fe, Mn, Zn, Cu) according to Lindsay and Norvel (1978), cation exchange capacity (CEC) by Bower method (US Salinity Laboratory Staff, 1954). Moisture contents in field capacity (FC) and permanent wilting point (PWP) were measured at a pressure plate apparatus under $1 / 3$ and $15 \mathrm{~atm}$ pressure after soils reached a hydraulic balance state, available water content (AWC) was determined by calculating the difference between FC and PWP (Black, 1965). Plant height (PH), thousand seed weight (TSW) and seed yield (SY) measurements in maize plant were determined within the principles reported by Anonymous (2018).

\section{Statistical analysis}

Descriptive statistics of soil and plant analysis results and correlations between soil properties and plant yield parameters were calculated in SPSS 17.0 package program, and regression models formed between yield parameters and soil properties were created in Minitab 17.0 package program. The indices of the statistical analysis, the root mean square error (RMSE), the index of agreement (d), the model efficiency (ME) were calculated using the following expressions, respectively:

$$
R M S E=\sqrt{\frac{1}{n_{i=1}} \sum_{i}^{n}\left(x_{i}-y_{i}\right)^{2}}
$$

where, $n$ - is the number of data, if $n<30 m=n$-1, if $n>30 m=n ; x_{i}$ - measured values; $y_{i}$ - estimaded values.

$$
d=1-\frac{\sum_{i=1}^{n}\left(x_{i}-y_{i}\right)^{2}}{\sum_{i=1}^{n}\left(\left|x_{i}-\bar{y}\right|+\left|y_{i}-\bar{y}\right|\right)^{2}}
$$

where, $\bar{y}$ is the mean measured values.

$$
M E=1-\frac{\sum_{i=1}^{n}\left(x_{i}-y_{i}\right)^{2}}{\sum_{i=1}^{n}\left(y_{i}-\bar{y}\right)^{2}}
$$

The root mean squares erorr is the standard deviation of the estimation errors. The index of agreement $(d)$ is an indicator of the validity of the model and the $d$ is close to 1 indicates the applicability of the model. In a study of the experimental hydrological model by Krause et al. (2005), ME values were shown to vary between 1 and $\infty$, and if the ME was smaller than zero, the measured mean value was more effective than the calculated value. Comparison of analytical expressions of $d$ and ME showed greater $d$ value than ME (Willmott and Matsuura, 2005; Willmott et al., 2012; Kumar et al., 2015; Wang et al., 2016).

\section{Results and Discussion}

\section{Distribution of maize plant yield parameters}

Results of the descriptive statistics of some yield parameters of maize plant grown in the research area were given in Table 1.

Table 1. Some descriptive statistics of some yield parameters of maize plant $(n=40)$

\begin{tabular}{lcccccc}
\hline Parameters & Minimum & Maximum & Mean & SD & CV, \% & Skewness \\
\hline PH, cm & 172.33 & 351.22 & 294.16 & 32.85 & 11.16 & -1.639 \\
TSW, g & 167.54 & 450.75 & 345.19 & 63.59 & 18.42 & -0.274 \\
SY, kg da-1 & 833.58 & 1584.37 & 1293.53 & 173.05 & 13.37 & -0.621 \\
\hline
\end{tabular}

PH: Plant height; TSW: Thousand seed weight; SY: Seed yield; SD: Standard deviation; CV: variation coefficient

The values of the yield indices of maize plant, namely PH, TSW and SY varied between $172.33-351.22 \mathrm{~cm}$, 167.54-450.75 g and 833.58-1584.37 $\mathrm{kg} \mathrm{da}^{-1}$ respectively, and their average values were $294.16 \mathrm{~cm}, 345.19$ g and $1293.37 \mathrm{~kg} \mathrm{da}^{-1}$, acordingly (Table 1 ). Statistical indicators vary within valid limits. Being the skewness values close to zero from the right and left, indicates that the distribution is close to normal. The SY had more than 2-5 times a higher standard deviation than that of PH or TSW, which could be associated with the wide range of seed yield and soil properties. 
Relationship between some yield parameters and some physical and chemical properties of soil

Correlation coefficients (r) of maize plant yield parameters and some physical and chemical parameters of soil were given in Table 2 . A significant positive correlation $(0.54, p<0.01)$ was found between thousand seed weight and seed yield. There was a significant correlation between SY value of maize plant and OM, Cu and $\mathrm{N}$ contents of soils, as well as between SY value and EC, P, K, Na and Zn contents ( $r>0.3-0.4)$ of the soil. There was no statistically significant correlations between the agronomic characteristics of the maize plant and the other physical and chemical parameters of the soil. Angelov (1994) also reported the significant and high correlation between seed yield and ripening time, plant height, number of leaves in the plant, first cob height. Karabulut and Ünver (2012) found a positive correlation between the parameters of clay and $\mathrm{K}, \mathrm{OM}$, $\mathrm{N}, \mathrm{CEC}(p<0.05)$, and negative correlation between sand and these properties in a study conducted in the farmer's field where maize was cultivated, reveling that plant yield is highly linked as soil properties as well as management.

Table 2. Correlation matrix for some yield parameters of maize plant and chemical and physical properties of soil

\begin{tabular}{|c|c|c|c|}
\hline Parameters & $\mathrm{PH}, \mathrm{cm}$ & TSW, g & SY, $\mathrm{kg} \mathrm{da}^{-1}$ \\
\hline $\mathrm{PH}, \mathrm{cm}$ & 1 & & \\
\hline TSW, g & -0.137 & 1 & \\
\hline $\mathrm{SY}, \mathrm{kg} \mathrm{da}^{-1}$ & -0.053 & $0.542^{* *}$ & 1 \\
\hline Clay, \% & -0.235 & 0.085 & 0.006 \\
\hline Silt, $\%$ & 0.123 & -0.225 & -0.197 \\
\hline Sand, \% & 0.147 & 0.055 & 0.112 \\
\hline $\mathrm{BD}, \mathrm{g} \mathrm{cm}^{-3}$ & 0.207 & 0.032 & -0.116 \\
\hline $\mathrm{FC}, \%$ & -0.332 & 0.344 & 0.212 \\
\hline PWP, \% & -0.322 & 0.361 & 0.287 \\
\hline AWC, \% & -0.276 & 0.247 & 0.051 \\
\hline $\mathrm{pH},(1: 1)$ & 0.020 & 0.255 & 0.117 \\
\hline EC, dS m ${ }^{-1}(1: 1)$ & -0.112 & $0.431^{*}$ & $0.384 *$ \\
\hline $\mathrm{CaCO}_{3}, \%$ & 0.068 & -0.029 & 0.236 \\
\hline $\mathrm{OM}, \%$ & -0.135 & $0.378^{*}$ & $0.518^{* *}$ \\
\hline $\mathrm{N}, \%$ & -0.236 & $0.637^{* *}$ & $0.655^{* *}$ \\
\hline $\mathrm{P}, \mathrm{ppm}$ & -0.051 & 0.024 & $0.377^{*}$ \\
\hline $\mathrm{K}, \mathrm{cmol} \mathrm{kg}^{-1}$ & -0.198 & 0.233 & $0.421 *$ \\
\hline $\mathrm{Ca}+\mathrm{Mg}, \mathrm{cmol} \mathrm{kg}^{-1}$ & -0.148 & 0.284 & 0.192 \\
\hline $\mathrm{Na}, \mathrm{cmol} \mathrm{kg}^{-1}$ & 0.095 & -0.006 & $0.403^{*}$ \\
\hline $\mathrm{CEC}, \mathrm{cmol} \mathrm{kg}^{-1}$ & -0.146 & 0.285 & 0.221 \\
\hline $\mathrm{Fe}, \mathrm{ppm}$ & -0.125 & -0.152 & -0.104 \\
\hline $\mathrm{Mn}, \mathrm{ppm}$ & -0.010 & -0.231 & -0.168 \\
\hline $\mathrm{Cu}, \mathrm{ppm}$ & -0.194 & $0.403^{*}$ & $0.556^{* *}$ \\
\hline $\mathrm{Zn}, \mathrm{ppm}$ & -0.074 & 0.220 & $0.409 *$ \\
\hline
\end{tabular}

\section{Regression models between yield parameters and some physical characteristics properties of soils}

Regression models between maize PH, TSW and SY and some physical characteristics of soils were given in Table 3. Results of the correlation analysis (Table 2) between yield parameters and soil physical characteristics were taken into consideration in the creation of regression models (Table 3 ).

Table 3. Regression models between maize plant height, thousand seed weight, seed yield and some physical characteristics of soils

\begin{tabular}{|c|c|c|c|c|}
\hline & Models & $\mathrm{R}$ & $\mathrm{F}$ & $\mathrm{p}$ \\
\hline 1. & $\mathrm{PH}=436-4.83$ Clay - 80 BD + 3.70 (BD×Clay) - 0.26 PWP - 0.87 FC & 0.451 & 1.12 & 0.378 \\
\hline 2. & $\begin{array}{l}\mathrm{PH}=1002-8.53 \text { Sand }-507 \mathrm{BD}-13.4 \text { Clay + } 6.15(\mathrm{BD} \times \text { Sand })+10.3(\mathrm{BD} \times \text { Clay })+2.17 \\
(\mathrm{BD} \times \mathrm{PWP})-0.070(\mathrm{PWP})^{2}-1.71 \mathrm{FC}\end{array}$ & 0.504 & 0.81 & 0.603 \\
\hline 3. & PH $=1034+4.4$ Clay - 284 BD - $114 \sqrt{\text { Clay }}-20.5 \sqrt{\text { Sand }}+7.17$ (BD×Clay) -2.40 FC + & 0.533 & 0.67 & 0.734 \\
\hline 4. & $\begin{array}{l}1.12 \mathrm{PWP}+30(\mathrm{BD})^{2}+0.32(\mathrm{BD} \times \text { Sand })-0.062(\text { Clay })^{2} \\
\mathrm{TSW}=-65+266 \mathrm{BD}+9.27 \text { Clay }+1.39 \mathrm{AWC}+2.86 \mathrm{PWP}-7.35(\mathrm{BD} \times \text { Clay })\end{array}$ & 0.425 & 0.97 & 0.455 \\
\hline 5. & $\begin{array}{l}\mathrm{TSW}=842-75 \mathrm{BD}+0.0435(\text { Clay })^{2}+1.02(\mathrm{BD} \times \text { Clay })-24.8 \sqrt{\text { Sand }}-3.40 \mathrm{FC}-69.0 \\
\sqrt{\text { Clay }}+6.10(\mathrm{BD} \times \mathrm{PWP})\end{array}$ & 0.510 & 1.10 & 0.402 \\
\hline 6. & $\begin{array}{l}\text { TSW }=-178+1700 \text { BD }-45 \sqrt{\text { Clay }}-70.2 \sqrt{\text { Sand }}-740(B D)^{2}+1.49(\mathrm{BD} \times \text { Clay })-3.98 \text { FC+ } \\
5.84(\mathrm{BD} \times \mathrm{PWP})+0.0075(\text { Clay })^{2}+3.20(\mathrm{BD} \times \text { Sand })\end{array}$ & 0.600 & 0.88 & 0.559 \\
\hline 7. & $\mathrm{SY}=1675-393 \mathrm{BD}+2.51$ Sand $+23.1 \mathrm{PWP}-9.5 \mathrm{FC}$ & 0.435 & 1.35 & 0.281 \\
\hline 8. & $\mathrm{SY}=1766-449 \mathrm{BD}+18.5$ Sand $-11.8(\mathrm{Db} \times \mathrm{Sand})+26.1(\mathrm{BD} \times \mathrm{PWP})-15.4 \mathrm{FC}$ & 0.529 & 1.71 & 0.174 \\
\hline 9. & $S Y=-43+4315$ BD -2.06 Silt $-10.1 F C-155 P W P+136(B D \times P W P)-2480(B D)^{2}$ & 0.682 & 3.04 & 0.027 \\
\hline
\end{tabular}

PH: Plant height; TSW: Thousand seed weight; SY: Seed yield. 
Coefficients of determination was varied between 0.45 and 0.53 in the regression models expressed by various polynomial functions between maize plant height and soil clay, sand, BD, FC, PWP characteristics (Table 3). The F value, used to determine whether interaction and major factors are significant, increased as the $\mathrm{p}$ value decreased. The regression coefficient was the highest $(\mathrm{R}=0.53)$ in the model number three, which was formed by clay, BD, sand, FC, PWP parameters and the lowest $(\mathrm{R}=0.45)$ in the model number one containing clay, BD, PWP and FC parameters (Table 3). However there was no statistically significant difference according to $\mathrm{p}$ values. For the models formed between the TSW and some physical properties of soils, the regression coefficients varied from 0.42 to 0.60 , and $F$ values from 0.88 to 1.10 , and p values from 0.402 to 0.559 . Regression coefficient $(\mathrm{R}=0.60)$ was found to be moderate in model number 6 , although there was no statistically significant difference between maize TSW and physical properties of soils (Table 3 ). Research shows that the expression of regression models with polynomials covering the square, square root and product of soil properties increases the regression coefficient and also the significance of the estimation (Kosheleva et al., 2002; Gülser and Candemir, 2014). In the models created between the physical properties properties of soils such as BD, sand, silt, PWP, FC and SY, the regression coefficients were between 0.43 and $0.68, \mathrm{~F}$ values were between 1.35 and 3.11, and p values were between 0.027 and 0.281 (Table 3). The highest statistically significant regression coefficient $(\mathrm{R}=0.68, p<0.05)$ were found in model 9 which included silt, bulk density, PWP and FC parameters. In the regression equations created by Malone et al. (2007) to estimate seed yield in maize and soybean plants, the coefficients of determination were reported to be $0.85-0.87$.

\section{Regression models between yield parameters and some chemical characteristics of soils}

Table 4. Regression models between maize plant height, thousand seed weight, seed yield and some chemical characteristics of soils

\begin{tabular}{|c|c|c|c|c|}
\hline & Models & $\mathrm{R}$ & $\mathrm{F}$ & $\mathrm{p}$ \\
\hline 1. & $\begin{array}{l}\mathrm{PH}=393+2.10(\mathrm{OM})^{2}+135(\mathrm{EC})^{2}-111 \sqrt{E C}-278 \mathrm{~N}-0.202 \mathrm{P}-46.0 \mathrm{~K}+2.77(\mathrm{~N} \times \mathrm{P} \times \mathrm{K})-0.00270 \\
(\mathrm{CEC})^{2}\end{array}$ & 0.358 & 0.35 & 0.935 \\
\hline 2. & $\begin{array}{l}\mathrm{PH}=322-3.54\left(\mathrm{CaCO}_{3}\right)^{2}+4.06(\mathrm{OM})^{2}+5.7(\mathrm{EC})^{2}-0.00247(\mathrm{CEC})^{2}-429 \mathrm{~N}-10.1 \mathrm{~K}-4.95 \mathrm{Cu}+ \\
28.9 \mathrm{CaCO}_{3}\end{array}$ & 0.372 & 0.38 & 0.916 \\
\hline 3. & $\begin{array}{l}\mathrm{PH}=-3-2.27\left(\mathrm{CaCO}_{3}\right)^{2}+17.0(\mathrm{OM})^{2}+32(\mathrm{EC})^{2}-3296 \mathrm{~N}+19.3 \mathrm{CaCO}_{3}-0.214 \mathrm{Ca}+\mathrm{Mg}- \\
70.1 \mathrm{OM}+2256 \sqrt{N}\end{array}$ & 0.433 & 0.46 & 0.881 \\
\hline 4. & $\mathrm{TSW}=66+21.3 \mathrm{pH}+188 \mathrm{EC}-10.6 \mathrm{CaCO}_{3}+26.3 \mathrm{OM}$ & 0.578 & 2.88 & 0.045 \\
\hline 5. & $\mathrm{TSW}=148+3.6 \mathrm{pH}+131 \mathrm{EC}-7.19 \mathrm{CaCO}_{3}-5.3 \mathrm{OM}+995 \mathrm{~N}$ & 0.680 & 3.79 & 0.013 \\
\hline 6. & $\begin{array}{l}\mathrm{TSW}=-760+56 \mathrm{EC}+16.4 \mathrm{CaCO}_{3}+60 \mathrm{OM}-7397 \mathrm{~N}+0.4548(\mathrm{Ca}+\mathrm{Mg})-204 \sqrt{O M}-106 \\
\sqrt{\mathrm{CaCO}_{3}}-0.0298(\mathrm{~N} \times \mathrm{P} \times \mathrm{K})^{2}+6442 \sqrt{N}\end{array}$ & 0.785 & 3.22 & 0.017 \\
\hline 7. & $\mathrm{SY}=820+142 \mathrm{EC}+13.8 \mathrm{OM}+2929 \mathrm{~N}+2.63 \mathrm{P}-112 \mathrm{~K}$ & 0.697 & 4.15 & 0.008 \\
\hline 8. & $\begin{array}{l}\mathrm{SY}=670+78 \mathrm{EC}-128 \mathrm{OM}+4058 \mathrm{~N}+3.56 \mathrm{P}-237 \mathrm{~K}+4.01(\mathrm{Ca}+\mathrm{Mg})+13.9 \mathrm{Cu}+67.7 \mathrm{Zn}+ \\
88.9 \mathrm{Na}\end{array}$ & 0.807 & 3.73 & 0.008 \\
\hline 9. & $\begin{array}{l}\mathrm{SY}=-3355-831 \mathrm{EC}+141 \mathrm{OM}-32480 \mathrm{~N}+4.46 \mathrm{P}-42 \mathrm{~K}-28.4 \mathrm{Cu}+100 \mathrm{Na}+713(\mathrm{EC})^{2}+ \\
0.0229(\mathrm{CEC})^{2}+26682 \sqrt{N}-557 \sqrt{O M}-3.96\left(\mathrm{CaCO}_{3}\right)^{2}\end{array}$ & 0.866 & 3.75 & 0.009 \\
\hline
\end{tabular}

PH: Plant height; TSW: Thousand seed weight; SY: Seed yield.

The regression models were formed by taking into consideration the results of the correlation analysis (Table 2) between the TSW and soil properties. As seen from regression models numbered (1)-(3) between maize $\mathrm{PH}$ and soil chemical parameters such as $\mathrm{EC}, \mathrm{OM}, \mathrm{CEC}, \mathrm{CaCO}_{3}, \mathrm{~N}, \mathrm{P}, \mathrm{K}, \mathrm{Cu}, \mathrm{Ca}+\mathrm{Mg}$, regression coefficients were low and not significant ( $p>0.1$ ), and ranged between 0.36 and 0.43 (Table 4). In model 6 including $\mathrm{EC}, \mathrm{CaCO}_{3}, \mathrm{OM}, \mathrm{N}, \mathrm{P}, \mathrm{K}, \mathrm{Ca}+\mathrm{Mg}$ parameters and square, product and square root of some parameters, improved the model anf regression coefficient was found to be the highest among the models 16 , and significant $(\mathrm{R}=0.79, p<0.05)$. Models (7)-(9) formed between maize SY and some chemical properties of soils, the regression coefficients of the models were higher and varied between 0.70 and 0.87 , with $\mathrm{p}$ values were between 0.008 and 0.009 , i.e. showed high statistical significance $(p<0.01)$ (Table 4). The highest regression coefficient ( $\mathrm{R}=0.87$ ) was obtained in the (9) model including $\mathrm{EC}, \mathrm{OM}, \mathrm{CEC}, \mathrm{CaCO}_{3}, \mathrm{~N}, \mathrm{P}, \mathrm{K}$, $\mathrm{Cu}, \mathrm{Na}$ parameters. Analogously, Jin et al. (2017) established regression models for wheat SY estimation, and reported the high and significant $\mathrm{R}\left(\mathrm{R}^{2}=0.42, p<0.01\right)$.

The validity of regression models formed between the yield parameters and some soil properties

In order to determine the validity of the used regression models (obtained from the experimental data) it should applied for the data other than the values used in the creation of the models or from the values in the data bank (Wang et al., 2016). Statistical parameters of the validity of the regression models between the maize of PH, TSW, SY and physical and chemical characteristics of the soils were given in Table 5. 
Table 5. Some statistical parameters of regression models of maize plant height, thousand seed weight and seed yield

\begin{tabular}{lcccc}
\hline Models (No) & R & RMSE & $d$ & ME \\
\hline PH (3) (P) & 0.533 & 14.580 & 0.984 & 0.160 \\
PH (3) (C) & 0.433 & 49.601 & 0.972 & -0.515 \\
TSW (3) (P) & 0.600 & 32.243 & 0.983 & -0.293 \\
TSW (3) (C) & 0.785 & 49.355 & 0.993 & 0.162 \\
SY (3) (P) & 0.682 & 38.171 & 0.997 & 0.869 \\
SY (3) (C) & 0.866 & 48.402 & 0.998 & 0.884 \\
\hline
\end{tabular}

PH: Plant height; TSW: thousand seed weight; SY: Seed yield; R: Regression coefficient; RMSE: Root mean square error; $d$ : index of agreement; ME: Model efficiency; P: physical properties of soils; C: chemical characteristics of soils

As shown in Table 5, descriptive statistics of regression models were generally within the validity limits. Karadavut et al. (2010), using three different models in a study that predicted dry matter accumulation in maize varieties, determined ME values betweeen 83 and. In a study conducted by Usowicz et al. (2013), RMSE value of the model used in the estimation of soil thermal conductivity was determined as 0.104 .

The comparison of calculated and measured PH, TSW, SY values according to third models was given in Figure 2. The $r$ values of linear relations calculated and measured according to the regression models between PH, TSW, SY and physical properties of the soils were $0.53,0.55$ and 0.78 , respectively, and were statistically significant at 0.01 level, showing that current approach could be used for such prediction.

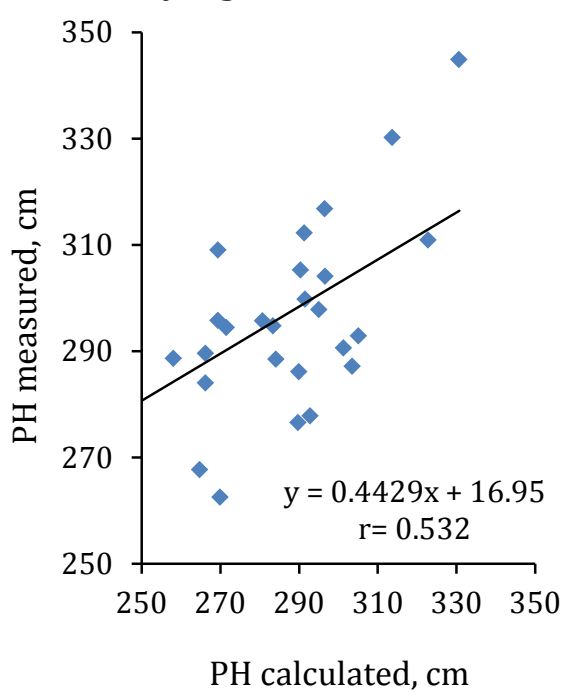

(a)

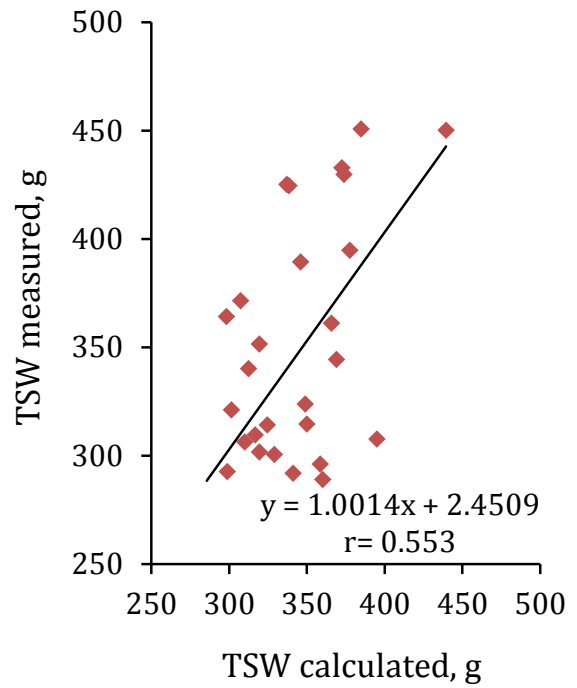

(b)

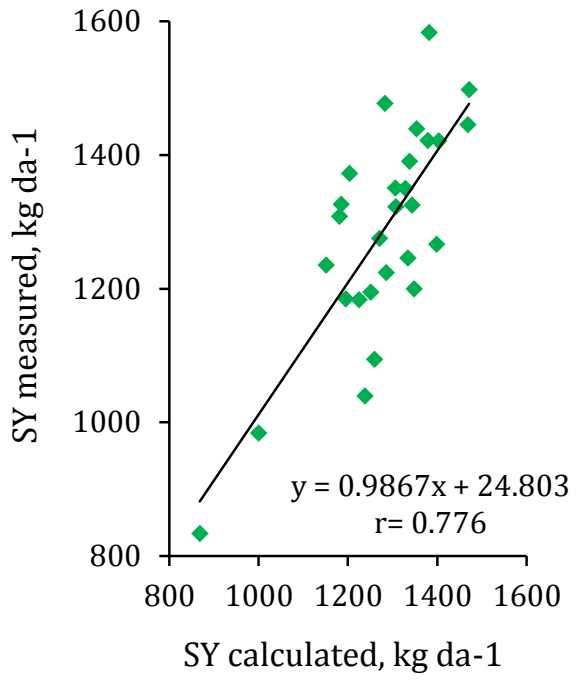

(c)

Figure 2. The relationship between calculated and measured plant height (A), thousand seed weight (B), seed yield (C) and physical properties of the soil according to regression models

\section{Conclusion}

It is important to determine the experimental relations between soil properties and yield parameters of agricultural land where different agricultural plants are grown, in evaluation and estimation of yield potential. Experimental relationships can evaluate quantitatively the interaction between yield and soil properties at the various scale (from field to watershed). Regression models have been established between some physical and chemical properties of agricultural soils, cultivated using traditional soil tillage methods and yield parameters of the maize, the main crop grown in Çarşamba Plain. In the formation of regression models, soil and plant parameters with significant and high correlation were taken as basis. The performance of the models including plant yield components (PH, TSW and SY) and square, product and square root of the soil parameters were found to be higher. The comparison of the measured and calculated yield values using regression models showed that the models obtained by evaluating statistical parameters were applicable to the estimation of yield parameters in maize grown soils of the region. Factors such as failure of regular agricultural operations (fertilization, irrigation, etc.) by the farmers in the study area, changes in climatic conditions, adversely affect the physical and chemical properties and cause soil properties to change over short distances or time intervals, and therefore affects the performance of the regression models between yield parameters and physical and chemical soil properties. For building and applying regression models, it is necessary to create a data bank of soil properties and yield components of different regression models for various plants at local and regional level. In addition, it is necessary to benefit from the data which is not used in the creation of the models to determine the validity of the regression models. 


\section{References}

Alexandrov, V.A., Hoogenboom, G., 2000. The impact of climate variability and change on crop yield in Bulgaria. Agricultural and Forest Meteorology 104(4): 315-327.

Angelov, K., 1994. Correlations between grain yield and certain plant and ear chracteristics in maize hybrids. Field Crop Abstracts. 47: 133.

Anonymous, 2018. Directorate of Seed Registration and Certification. Available at [access date: 19.02.2019]: https://www.tarimorman.gov.tr/BUGEM/TTSM/Belgeler/Tescil/Teknik\%20Talimatlar/S\%C4\%B1cak\%20\%C4 \%B0klim\%20Tah\%C4\%B1llar\%C4\%B1/MISIR_TEKNIK_TALIMATI.pdf

Anonymous, 2019. Turkish Statistical Institute Main Statistics. Available at [access date: 19.02.2019]: https://biruni.tuik.gov.tr/medas/?kn=92\&locale=tr

Bayraklı, F., Ekberli, İ.A., Gülser, C., 1999. Azerbaycan Mil ovası topraklarının verimlilik düzeylerinin deneysel ve matematiksel olarak değerlendirilmesi. OMU Ziraat Fakültesi Dergisi 14(2): 138-153 [in Turkish].

Black, C.A., 1965. Methods of Soil Analysis, Part II - Chemical and Microbiological Properties. Agronomy Monograph 9.1, American Society of Agronomy (ASA), Soil Science Society of America (SSSA), Madison, Wisconsin, USA.

Bouma, J., van Lanen, H.A.J., 1987. Transfer functions and threshold values: from soil characteristics to land qualities. In: Proceedings of the International Workshop on Quantified Land Evaluation Procedures. Beek, K.J., Burrough, P.A., MacCormack, D.E. (Eds.). 27 April - 2 May 1986, Washington, D.C., USA, pp. 106-110.

Bouyoucos, G.J., 1962. Hydrometer method improved for making particle size analyses of soils. Agronomy Journal 54(5): 464-465.

Budka, A., Łacka, A., Gaj, R., Jajor, E., Korbas, K., 2015. Predicting winter wheat yields by comparing regression equations. Crop Protection 78: 84-91.

Çolakoğlu, H., 1985. Gübre ve Gübreleme. Ege Üniversitesi Ziraat Fakültesi Yayınları, Teksir No:17, Bornova, İzmir, Turkey [in Turkish].

Demiralay, İ., 1993. Toprak Fiziksel Analizleri. Atatürk Üniversitesi Ziraat Fakültesi Yayınları No:143, Erzurum, Turkey [in Turkish].

Dengiz, O., Ekberli, İ., 2017. Bazı vertisol alt grup topraklarının fizikokimyasal ve ısısal özelliklerinin incelenmesi. Akademik Ziraat Dergisi 6(1): 45-52 [in Turkish].

Dorsey, J.W., Hardy, L.C., 2018 Sustainability factors in dynamical systems modeling: Simulating the non-linear aspects of multiple equilibria. Ecological Modelling 368: 69-77.

Dotlacil, L., Toman, K., 1991. Testability of the yield of different wheat varieties. Rostlinna Vyroba,37: 33-38.

Ekberli, İ., Dengiz, O., 2016. Bazı inceptisol ve entisol alt grup topraklarının fizikokimyasal özellikleriyle isısal yayınım katsayısı arasındaki regresyon ilişkilerin belirlenmesi. Toprak Su Dergisi 5(2): 1-10 [in Turkish].

Gülser, C., 2004. Tarla kapasitesi ve devamlı solma noktası değerlerinin toprakların fiziksel ve kimyasal özellikleriyle ilişkili pedotransfer eşitliklerle belirlenmesi. OMU Ziraat Fakültesi Dergisi 19(3): 19-23 [in Turkish].

Gülser, C., Candemir, F., 2014. Using soil moisture constants and physical properties to predict saturated hydraulic conductivity. Eurasian Journal of Soil Science 3(1): 77-81.

Gülser, C., Ekberli, I., Candemir F., 2016. Spatial variability of soil physical properties in a cultivated field. Eurasian Journal of Soil Science 5(3): 192-200.

Carena, M.J., Hallauer, A.R., Miranda Filho, J.B., 1987. Quantitative Genetics in Maize Breeding. Springer, New York, USA.

Huang, F., Zhan, W., Ju, W., Wang, Z., 2014. Improved reconstruction of soil thermal field using two-depth measurements of soil temperature. Journal of Hydrology 519: 711-719.

Jin, X., Li, Z., Yang, G., Yang, H., Feng, H., Xu, X., Wang, J., Li, X., Luo, J., 2017. Winter wheat yield estimation based on multi-source medium resolution optical and radar imaging data and the AquaCrop model using the particle swarm optimization algorithm. ISPRS Journal of Photogrammetry and Remote Sensing 126: 24-37.

Kacar, B., 1994. Bitki ve Toprağın Kimyasal Analizleri III. Toprak Analizleri. Ankara Üniversitesi Ziraat Fakültesi Eğitim Araştırma ve Geliștirme Vakfı Yayınları No:3. Ankara, Turkey [in Turkish].

Karabulut, A., Ünver, İ., 2012. Çukurova'da alüvyal bir tarım arazisinde bazı toprak verimlilik parametrelerinin jeoistatistiksel modellemesi. Toprak Su Dergisi 1(2): 71-81 [in Turkish].

Karadavut, U., Genç, A., Tozluca, A., Palta, Ç., 2010. Silajlık ve danelik mısırlarda kuru madde birikiminin bazı matematiksel büyüme modelleri ile analizi. Tarım Bilimleri Dergisi 16: 89-96 [in Turkish].

Kars, N., Ekberli, İ., 2019a. Çarşamba ovasının buğday bitkisi altındaki topraklarının bazı fiziksel ve kimyasal özelliklerinin incelenmesi. Toprak Su Dergisi 8(1): 18-28 [in Turkish].

Kars, N., Ekberli, İ., 2019b. Buğday bitkisinin verim parametreleri ile bazı toprak özellikleri arasındaki pedotransfer modellerin uygulanabilirliği. Türkiye Tarımsal Araştırmalar Dergisi 6(2): 153-164 [in Turkish].

Kosheleva, N.E., Kasimov, N.S., Samonova, O.A., 2002. Regression models for the behavior of heavy metals in soils of the Smolensk-Moscow Upland. Eurasian Soil Science 35(8): 845-856.

Kumar, A., Pandey, V., Shekh, A.M., Dixit, S.K., Kumar, M., 2008. Evaluation of cropgro-soybean (Glycine max. [1] (merrill) model under varying environment condition. American-Eurasian Journal of Agronomy 1(2): 34-40.

Lindsay, W.L., Norvell, W.A., 1978. Development of a DTPA Test for zinc, iron, manganese and copper. Soil Science Society America Journal 42(3): 421-428.

Maiti, R.K., Wersche-Ebeling, P., 1998. Maize Science. Science Publishers, Inc. Enfield, USA. 520 p.

Malone, R.W., Ma, L., Karlen, D.L., Meade, T., Meek, D., Heilman, P., Kanwar, R.S., Hatfield, J.L., 2007. Empirical analysis 
and prediction of nitrate loading and crop yield for corn-soybean rotations. Geoderma 140(3): 223-234.

Nelson, R.E., 1982. Carbonate and gypsum. In: Methods of Soil Analysis, Part 2, Chemical and microbiological properties, Second Edition. Number 9, Page, A.L., Keeney, D. R., Baker, D.E., Miller, R.H., Ellis, R. Jr., Rhoades, J.D. (Eds.). ASASSSA, Madison, Wisconsin, USA. pp. 181-198.

Olsen, S.R., Cole, C.V., Watanabe, F.S., Dean, L.A., 1954. Estimation of available phosphorus in soils by extraction with sodium bicarbonate. U.S. Department of Agriculture, Circular No 939, USA, 19p.

Overman, A.R., Scholtz, III R.V., 2002. Mathematical models of crop growth and yield. Marcel Dekker Inc. New York, USA. 325p.

Pachepsky, Y. A., Rawls, W.J., 2004. Development of pedotransfer functions in soil hidrology. Develoment in Soil Science, Elsevier, Volume 30, 542p.

Peterson, C.J., Graybosch, R.A., Baenziger, P.S., Grombacher, A.W., 1992. Genotype and environment effects on quality characteristics of hard red winter wheat. Crop Science 32(1): 98-103.

Rowell, D.L., 1994. Soil science: methods and applications. Longman Group Ltd., London, UK. 350 p.

Thiéry, D., Amraoui, N., Noyer, M.L., 2018. Modelling flow and heat transfer through unsaturated chalk - Validation with experimental data from the ground surface to the aquifer. Journal of Hydrology 556: 660-673.

U.S. Salinity Laboratory Staff., 1954. Diagnosis and Improvement of Saline and Alkali Soils, Agriculture. Handbook No:60, United States Department of Agriculture, Washington DC, USA. 160p. Available at [access date: 19.02.2019]: https://www.ars.usda.gov/ARSUserFiles/20360500/hb60_pdf/hb60complete.pdf

Usowicz, B., Lipiec, J., Usowicz, J.B., Marczewski, W., 2013. Effects of aggregate size on soil thermal conductivity: Comparison of measured and model-predicted data. International Journal of Heat and Mass Transfer 57(2): 536541.

Vereecken, H., Weynants, M., Javaux, M., Pachepsky, Y.A., Schaap, M.G., van Genuchten, M.T., 2010. Using pedotransfer functions to estimate the van Genuchten-Mualem soil hydraulic properties: A review. Vadose Zone Journal 9(4): 795-820.

Walkley, A., Black, I.A., 1934. An examination of Degtjareff method for determining soil organic matter and a proposed modification of the chromic acid titration method. Soil Science 37(1): 29-37.

Wang, L., Li, X., Chen, Y., Yang, K., Chen, D., Zhou, J., Liu, W., Qi, J., Huang, J. 2016. Validation of the global land data assimilation system based on measurements of soil temperature profiles. Agricultural and Forest Meteorology 218-219: 288-297.

Whitman, C.E., Haffield, J.L., Reginato, R.J., 1985. Effect of slope position on the microclimate, growth and yield of barley. Agronomy Journal 77(5): 663-669.

Willmott, C.J., Matsuura, K., 2005. Advantages of the mean absolute error (MAE) over the root mean square error (RMSE) in assessing average model performance. Climate Research 30(1): 79-82.

Willmott, C.J., Robeson, S.M., Matsuura, K., 2012. Short Communication, A refined index of model performance. International Journal of Climatology 32(13): 2088-2094. 